\title{
Protection Forest: A New Dimension for Biodiversity Conservation, Sustainable Forest Management and Livelihood Improvement
}

\author{
Prakash Lamsal ${ }^{1}$ \\ Email : pplamsal@yahoo.com
}

\begin{abstract}
Protected areas have greater role in the biodiversity conservation, sustainable forest management and livelihood improvement. Government of Nepal has different provisions for the management of such areas. Centralized conservation concept has broadened to participatory and people centred approach. Landscape approach is the latest one in this field. There are various benefits of the declaration of the protected forest, and initiatives are also being taken from the Governmental sector, but along with that several negative impacts are also being witnessed. A clear strategy is needed in this regard. This paper talks about the development of the participatory approach, government initiatives and positive and negative impacts and the challenges ahead.
\end{abstract}

Key Words: Master Plan, Protection forest, Conservation approach, Positive and negative Impacts.

\section{Introduction}

Development and implementation of Master Plan for the Forestry Sector during 1990s can be considered as a turning point in the evolution of Nepal's forestry sector. Government controlled and centralized management systems slowly turned to keep in focuses the people's needs and aspirations. There were accompanying changes in the role of forestry field staff and offices too. Their added role of facilitators strengthened the mutual cooperation amongst themselves and the local communities. The general overall orientation of forest management and biodiversity conservation were made more participatory and people centered.

Promulgation of Forest Act 2049, regulations 2051 and amendment of National Parks and Wildlife Protection Act 2029 and its regulations, implementation of programs like community forestry development, buffer zone development, and formation of conservation areas have made the roles and responsibilities of stakeholders much clearer.

\footnotetext{
${ }^{1}$ Project Manager, Terai Arc Landscape Program, Dhanagadi
} 
The figure below shows how forestry sector in Nepal has evolved and has generally oriented towards people centered and landscape level conservation.

\section{Present Scenario}

The government of Nepal has embarked towards participatory and integrated biodiversity conservation approaches from its initial emphases on species focused and site based management. Policy, Acts and Regulations have been formulated/amended and put in action. Country's national and international commitments for conservation and sustainable use of biodiversity resources were thus in action. The scope of biodiversity conservation has been broaden from conventional protected areas (National Parks, wildlife reserves and hunting reserves) to conservation areas, community forestry and buffer zones and even broadened to landscape level to include all form of protected areas and forest management. Landscape approach to biodiversity conservation can thus be considered as complementary to the earlier protected area and site focused management. Restoration and rehabilitation of corridor and connectivity areas between wildlife habitats is the priority activity of this concept. Further to this, it has been realized that some forests of national and international importance with unique biological and cultural values exist and that these important hotspots need specialized operations. Further, the inhabitants surrounding such areas (the impact zone communities) have certain anticipated roles and responsibilities for conservation and management. It therefore implies for special policy and legal ground to support the management of these forests and livelihood improvement of surrounding communities. The present generalized community forestry and other participatory management systems are not enough to support in this dimension. It has been practically seen that the interventions are well beyond the approved community forestry guidelines which are more focused on management of forests for the supply of forest products. The community forests of Khata area of Bardiya District and Bashanta of Kailali District are the practical examples. Some of the initiatives in these areas to mention are

- Species conservation activities that include anti poaching, specific habitat improvement for large mammals like One Horn Rhinoceros, grassland management for the maintenance of tigers prey base and so on

- Livelihood improvement activities including support to local cooperatives, income generation from green enterprise

- Sustainable forest management including forest management for fuel wood and timber, alternative energy promotion to reduce pressure in the forests

- $\quad$ Private plantations, support to livestock improvement and management

Department of Forests under the Ministry of Forests and Soil Conservation, with support from WWF Nepal and UNDP, is presently implementing programs like Terai Arc Lancscape, Western Terai Landscape Complex Project and are supporting the interventions mentioned above. To sustain the successful initiatives, a strong policy back up was felt necessary. Realizing this fact, the Ministry of Forests and Soil Conservation has recently brought out the policy of conserving corridor and connectivity areas through declaring them as special 
protection forests. The forests include identified corridors, bottlenecks and some critically important forests of the hills.

Thus, with the ultimate objectives of supporting smooth wildlife movement on the one hand and on the other contributing to poverty alleviation objective of the country yet another forest management modality has been initiated standing on the Forest Act 2049, part 4 point 23(1). Forests endowed with rich biodiversity, religious, cultural and historical values now have unique legal and policy status called Protection Forests.

The following national and international valued forests are declared as conservation areas as per the Forest Act 1993. Paragraph 4 and point 23 (1)

1. Barandabhar Forest, Chitwan

2. Panchase Panchadham Jungle

3. Madane Ban area

4. Khata Wildlife Corridor

5. Basanta Wildlife Corridor

6. Mohana Laljhadi Wildlife Corridor

It is hoped that with this initiatives, the conservation and development work will be implemented very effectively and efficiently in this areas. The ongoing deforestation and degradation will be minimized and present conservation initiatives outside the protected areas will have policy as well as legal support. These especially valued forests deserve special treatments and that adjoining impacted communities deserve the right of getting especial livelihood improvement programs for their corresponding role in the protection and management of protection forests..

Declaration of Protection Forests will not have any negative impacts in the existing forest management systems and to the participating societies. However, it will impart the following positive impacts

- Diversification of forest management systems to include habitat improvement, species conservation, restoration of corridors and connectivity

- Legal and policy avenue will be opened to manage identified critical corridors and connecting forests can be managed as part of an landscape level integrated conservation

- Special programmatic activities can be instituonalised to implement in the impact area of these identified protection forests

- Community based biodiversity and sustainable forest management will be further strengthened and the rights and responsibilities of participating communities consolidated 
- Nepal will play further positive role of conservation in the international sphere of which Nepal is member. And will help Nepal to fulfill its international obligations

There are challenges ahead to effectively achieve those impacts

- Formulation of protection forest management guidelines, strategies and governance modalities and get officially agreed with the government

- Preparation of Protection Forest Management Plans (PFMP) in a participatory and inclusive manner

- Raising awareness on the advantages of protection forests

- Reorientation and revision of participatory forestry management plans to include the especial operation required and livelihood improvement measures

- Reorientation of forestry field staff, stakeholders to streamline the conservation issues

- Technical and financial supports to the participating communities and district forest offices

\section{Final Point}

Conservation can not be achieved in isolation. Biodiversity conservation and sustainable forest management go hand on hand with the livelihood improvement of the participating communities. Conservation, therefore, is also the ultimate way for the sustainable improvement of our own livelihoods. Especially designed programmatic, legal and policy arrangements for the conservation of important forest areas through the declaration of Protection Forests will certainly add yet another dimension for biodiversity conservation and livelihood improvement in Nepal. Ever broadening participatory forest management process will be more strengthened and instituonalized and that development of forestry for livelihood improvement and vice versa will come with more consolidated actions. 